\title{
Genetic structure of bisexual and parthenogenetic populations of Artemia from Italian brackish-hypersaline waters
}

\section{Structure génétique des populations bisexuelles et parthénogénétiques d'Artemia des eaux saumâtres à hypersalées en Italie}

\author{
Giuseppe Nascetti *, Paola Bondanelli, Antonella Aldinucci, Roberta Cimmaruta \\ Department of Environmental Sciences, Tuscia University, Piazza dell'Università, 01100 Viterbo, Italy
}

Received 31 July 2002; accepted 30 September 2002

\begin{abstract}
Eight populations of Artemia displaying different reproduction modalities (amphigonic vs. parthenogenetic) and ploidies (diploid vs. polyploid) have been collected from Italian salt-works or brackish coastal lagoons, and their genetic structure has been investigated using allozyme electrophoresis. The results obtained on genetic differentiation showed that the Tyrrhenian bisexual samples (A. salina) are genetically homogeneous even between populations located in relatively faraway sites (Sardinia-Latium), having a moderate gene flow assisted by migratory waterfowl. The parthenogenetic samples (A.parthenogenetica) are genetically well differentiated both from the bisexual ones and among them, even when characterised by the same ploidy. Each sample presents few genotypes (i.e. few or single clones have been found in each sampling site), well distinguished from all the others. Further results concern the levels of genetic variability recorded. The parthenogenetic populations have an extremely high level of heterozygosity, due to a remarkable number of loci showing fixed heterozygosity, up to 13 out of 18 analysed. The preliminary data presented here show that some strains of A. parthenogenetica have a number of biological features typical of species of hybrid origin: fixed heterozygosity at many loci, parthenogenetic reproduction and genome polyploidisation. While too preliminary to advance a new hypothesis on the origin of $A$. parthenogenetica, our data suggest that further studies need to be carried out aimed at the research of possible bisexual parental species of $A$. parthenogenetica suspected hybrid strains.
\end{abstract}

(C) 2003 Éditions scientifiques et médicales Elsevier SAS and Ifremer/CNRS/IRD. All rights reserved.

\section{Résumé}

L'électrophorèse multilocus a permis de caractériser génétiquement huit populations d'Artemia provenant aussi bien d'étangs saumâtres que de lagunes côtières italiennes. Ces populations sont caractérisées par des modes de reproduction différents (amphigonie à parthénogenèse) et par différents degrés de ploïdie (diploïdie à polyploïdie). Les échantillons bisexuels qui viennent de la mer Tyrrhénienne sont génétiquement homogènes même s'ils sont géographiquement lointains (Sardaigne-Latium), grâce à un faible flux génétique probablement dû à la dispersion par des oiseaux migrateurs. Les échantillons parthénogénétiques (A. parthenogenetica) sont génétiquement différents entre eux ou comparés aux bisexuels, qu'ils aient ou non le même degré de ploïdie. Chaque population est composée d'un nombre limité de génotypes nettement différents les uns des autres. Les populations parthénogénétiques ont des niveaux d'hétérozygotie extrêmement élevés puisqu'un grand pourcentage des locus étudiés montre une hétérozygotie fixe (jusqu'à 13 locus sur 18). Ces donnés préliminaires prouvent que certains clones d'A. parthenogenetica présentent plusieurs caractères biologiques typiques d'une espèce hybride : hétérozygotie fixée à plusieurs locus, reproduction par parthénogenèse et polyplö̈disation du génome. Ces donnés sont cependant trop préliminaires pour avancer de nouvelles hypothèses concernant l'origine d'A. parthenogenetica, mais ils soulignent la nécessité d'identifier les espèces bisexuelles parentales des clones de A. parthenogenetica qui pourraient avoir une origine hybride.

(C) 2003 Éditions scientifiques et médicales Elsevier SAS and Ifremer/CNRS/IRD. Tous droits réservés.

Keywords:Artemia; Allozymes; Amphigony; Parthenogenesis; Heterozygosity

Mots clés : Artemia ; Allozymes ; Reproduction amphigonique ; Parthénogenèse ; Hétérozygotie

\footnotetext{
* Corresponding author.

E-mail address: nascetti@unitus.it (G. Nascetti).
} 


\section{Introduction}

Brackish waters are habitats characterised by strong seasonal fluctuations of environmental parameters, mainly temperature and salinity. These make them particularly suitable environments to investigate the relationships between environmental challenge and biological features adapting local populations to these "extreme" habitats. Within crustaceans, the anostracans belonging to Artemia genus are particularly well adapted to hypersalted habitats, responding to environmental changes with many adaptive strategies, including parthenogenetic reproduction and/or genome polyploidisation. Consequently, brine shrimp is a good target species to address the above-mentioned ecological and evolutionary questions concerning the relationships between reproductive modalities, evolutionary history and environmental stress (Browne, 1992 and references herein).

Although distributed in all continents except Antarctica, brine shrimp habitat is restricted to hypersaline inland lakes and coastal salterns, often associated with commercial salt production (Browne and MacDonald, 1982). In the American continent, Artemia reproduces only by bisexual reproduction and three species have been described, A. persimilis, A. franciscana and A. monica (Bowen et al., 1978). In the Old World and Australia, Artemia consists of a number of siblings or morphologically similar species divided into sexual diploid and obligate parthenogenetic, although obligate parthenogenesis is the method of reproduction for approximately $70 \%$ of the populations (Browne and MacDonald, 1982). There are many bisexual species so far described and their number will increase together with the number of genetic investigations carried out on this complex, since it is characterised by a high number of sibling species (Browne, 1992; Triantaphyllidis et al., 1997; Abatzopoulos et al., 2002). In the Mediterranean region (southern Europe and North Africa), there is a single bisexual species, A. salina, previously called A. tunisiana (Bowen et al., 1978; Browne, 1983, 1988; Mura, 1990), as demonstrated by recent morphological and molecular studies (Triantaphyllidis et al., 1997). All the parthenogenetic species of the Old World are grouped collectively under the single binomen A. parthenogenetica, including both diploid and polyploid strains (Bowen and Sterling, 1978). This classification is, however, recognised as inadequate, because remarkable levels of genetic divergence have been observed between different strains using allozymes and molecular markers (Abreu-Grobois and Beardmore, 1982; Perez et al., 1994).

Recent works suggest that asexual polyploid clones evolved by autopolyploidisation from parthenogenetic diploid Artemia, branched in turn from a bisexual ancestor (possibly A. urmiana or A. salina) approximately 5.4 million years ago (Abreu-Grobois and Beardmore, 1982; Browne and Bowen, 1991; Browne 1992). According to this hypothesis, the high genetic variability typical of $A$. parthenogenetica would be due to the interaction between genetic variation (originating by mutation and recombination, the latter acting in diploid forms only) and environmental selection (Barigozzi, 1974; Browne, 1992; Zhang and King, 1992; Browne et al., 2002). As a consequence, the genetic divergence between cytotypes should be due to environment dependent selection rather than their phylogenetic history. All the strains included in the A. parthenogenetica complex would be, therefore, of monophyletic origin.

The present research is part of a national project aimed at analysing the biodiversity in brackish-hypersaline waters. Thus, we have examined the genetic structure of the widely studied branchiopods $A$. salina and A. parthenogenetica using allozyme electrophoresis. The aim was to produce an overall view of the genetics of a large part of the Italian populations. Although in the past single Italian populations have been studied by many authors (Abreu-Grobois and Beardmore, 1982; Zhang and King, 1992; Pilla and Beardmore, 1994; Badaracco et al., 1995; Triantaphyllidis et al., 1997), an inclusive outline is still lacking. Given the genetic complexity of the species, the availability of data collected at the same time on different populations could be important for further studies on the evolution and ecology of this crustacean.

\section{Materials and methods}

A total of 746 Artemia specimens were collected from seven sites in Italian brackish-hypersaline waters: four samples of bisexual A. salina from Tyrrhenian Sea (Tarquinia, S. Antioco, Cagliari, and Putzu Idu) and four samples of A. parthenogenetica from Adriatic Sea (Cervia, Comacchio, and Margherita di Savoia). The latter sample has both diploid and tetraploid strains, as already evidenced by AbreuGrobois and Beardmore (1982) and confirmed by preliminary cytogenetic studies on karyotype (our unpublished data). The sampling locations are given in Table 1

Standard horizontal starch gel electrophoresis (12\%) was carried out on the whole organism. A total of 18 loci encoded by 15 enzymes were analysed as shown in Table 2 Allozymes were named numerically, according to their mobility relative to the most common allele (called 100) in the reference population from Tarquinia. To be sure that no "alien" species were sampled instead of A. salina or A. parthenogenetica, a population of $A$. franciscana from Salt Lake City (USA) was used as reference material: 10 of the 12 loci scored showed fixed allelic differences with respect to the Italian samples (Mdh-1, Mdh-2, Mdhp, Idh-2, Est, Pep-B, Ca, Mpi, Gpi, Pgm vs. Ldh, 6Pgdh).

Statistic analyses on allozyme data were performed using the computer package Biosys-1 (Swofford and Selander, 1989). Genotypic distributions at all loci were tested for conformance to Hardy-Weinberg expectations in bisexual populations using the exact probability test. Genetic variability was estimated in bisexual populations by the following parameters: (1) percentage of polymorphic loci, using the $0.99\left(P_{99}\right)$ criterion; $(2)$ overall number of alleles per locus $(A)$; $(3)$ observed mean heterozygosity per locus $\left(H_{\mathrm{o}}\right)$. Ob- 
Table 1

Population codes with relative reproductive modality and ploidy, collecting sites and number of specimens genetically analysed

\begin{tabular}{|c|c|c|c|c|c|c|}
\hline Species & Collecting sites & Abbreviation & Location & Reproductive modality & Ploidy & No. of specimens \\
\hline A. salina & Tarquinia & TAR & Latium & Amphigonic & Diploid & 156 \\
\hline$"$ & S. Antioco & SAN & Sardinia & $"$ & $"$ & 115 \\
\hline$"$ & Cagliari & CAG & $"$ & $"$ & $"$ & 123 \\
\hline$"$ & Putzu Idu & PUZ & $"$ & $"$ & $"$ & 95 \\
\hline A. parthenogenetica & Cervia & CER & Emilia Romagna & Parthenogenetic & Tetraploid & 73 \\
\hline$"$ & Comacchio & $\mathrm{COM}$ & $"$ & $"$ & $"$ & 112 \\
\hline$"$ & Margherita di Savoia & MSD & Apulia & & Diploid & 67 \\
\hline$"$ & Margherita di Savoia & MST & " & $"$ & Tetraploid & 5 \\
\hline
\end{tabular}

Table 2

The enzymes scored, listed with their international code (EEC), encoding loci, electrophoretic migration conditions and staining references

\begin{tabular}{|c|c|c|c|c|c|c|}
\hline Enzymes & EEC & Encoding loci & Migration & Buffer system $^{a}$ & $\mathrm{~V} / \mathrm{cm}$ & Ref. $^{b}$ \\
\hline$\alpha$-glycerophosphate dehydrogenase & 1.1 .1 .8 & $\alpha-G p d h$ & + & 2 & 8 & $\mathrm{~d}$ \\
\hline Lactate dehydrogenase & 1.1.1.28 & $L d h$ & + & 4 & 8 & $\mathrm{a}$ \\
\hline \multirow[t]{2}{*}{ Malate dehydrogenase } & 1.1.1.37 & $M d h-1$ & + & 5 & 8 & $\mathrm{~b}$ \\
\hline & & $M d h-2$ & + & & & \\
\hline NADP-Malate dehydrogenase & 1.1.1.40 & $M d h p$ & + & 2 & 8 & $\mathrm{~d}$ \\
\hline \multirow[t]{2}{*}{ Isocitrate dehydrogenase } & 1.1.1.42 & Idh-1 & + & $2-4$ & 8 & $\mathrm{~b}$ \\
\hline & & $I d h-2$ & + & & & \\
\hline 6-Phosphogluconate dehydrogenase & 1.1.1.44 & $6 P g d h$ & + & 5 & 8 & $\mathrm{~b}$ \\
\hline Superoxide dismutase & 1.15.1.1 & Sod & + & $2-4$ & 8 & $\mathrm{c}$ \\
\hline \multirow[t]{2}{*}{ Aspartate aminotransferase } & 2.6.1.1 & Aat-1 & + & 1 & 8 & $\mathrm{~b}$ \\
\hline & & Aat-2 & + & & & \\
\hline Esterase & 3.1 .1 .1 & Est & + & $1-3$ & 8 & $\mathrm{~d}$ \\
\hline Peptidase (Leu-Gly-Gly) & 3.4 .11 & Pep-B & + & 2 & 8 & $\mathrm{f}$ \\
\hline Aldolase & 4.1.2.13 & Ald & + & 1 & 8 & $\mathrm{~d}$ \\
\hline Carbonic anhydrase & 4.2.1.1 & $\mathrm{Ca}$ & + & 3 & 8 & $\mathrm{e}$ \\
\hline Mannose-6-phosphate isomerase & 5.3.1.8 & $M p i$ & + & 2 & 8 & $\mathrm{e}$ \\
\hline Glucose-6-phosphate isomerase & 5.3 .1 .9 & Gpi & - & 3 & 8 & $\mathrm{c}$ \\
\hline Phosphoglucomutase & 5.4.2.2 & Pgm & + & 4 & 8 & $\mathrm{a}$ \\
\hline
\end{tabular}

$\begin{aligned}+ & =\text { anodal. } \\ - & =\text { cathodal. }\end{aligned}$

${ }^{a}$ Buffer systems are the following: (1) discontinuous tris/citrate (Poulik, 1957); (2) continuous tris/citrate (Selander et al., 1971); (3) tris/versene/borate (Brewer and Sing, 1970); (4) tris/versene/maleate (Brewer and Sing, 1970); (5) phosphate/citrate (Harris and Hopkinson, 1976).

${ }^{b}$ Staining references: (a) Brewer and Sing (1970); (b) Shaw and Prasad (1970); (c) Selander et al. (1971); (d) Ayala et al. (1972); (e) Harris and Hopkinson (1976); (f) Richardson et al. (1986).

served mean heterozygosity has also been calculated for A. parthenogenetica samples. Genetic structuring within and between populations was calculated using the $F$ statistics by Wright $(1943,1951)$. The statistical significance of $F_{\mathrm{ST}}$ was assessed using the computer software FSTAT (Goudet, 2001) and the method of Workman and Niswander (1970). Genetic divergence was estimated using distance indices by Nei $\left(1972, D_{\mathrm{Nei}}\right)$, further used to build up an unweighted pair group method with arithmetic mean (UPGMA) dendrogram showing the genetic relationships between studied populations.

The amount of gene flow between bisexual populations was estimated by means of the parameter $\mathrm{Nm}$, where $m$ is the fraction of immigrants in a population of effective size $N$, using the formula proposed by Wright $(1943,1951)$, modified by Crow and Aoki (1984): $N m=\left[\left(1 / F_{\mathrm{ST}}\right)-1\right] / 4 \alpha$ where $F_{\mathrm{ST}}$ is the standardised variance of allele frequencies (averaged over variable loci) and $\alpha=(n / n-1)^{2}$, with $n$ being the number of populations sampled.

\section{Results}

\subsection{Genetic structure in amphigonic populations}

Six of the 18 loci analysed (Ldh, Mdhp, Aat-2, Ald, Est, $\mathrm{Ca}$ ) were found to be monomorphic for the same allele in all the samples tested. At six loci $(\alpha-G p d h, M d h-1, M d h-2$, $I d h-2$, Pep-B, Gpi), the frequency of the most common allele was higher than 0.90 in all the samples. The remaining six variable loci were found to be polymorphic (Idh-1, Sod, Aat-1) or highly polymorphic (6Pgdh, Mpi, Pgm) in all the four amphigonic populations with $2-6$ alleles per locus Table 3. Seven private alleles, i.e. alleles observed in a single population (Neel, 1973), have been found at five loci $(\alpha-G p d h, M d h-1, I d h-2,6 P g d h, P g m)$. They are all at low percentages, generally close to $1 \%$, except $I d h-2^{90}$ at $8.9 \%$ in S. Antioco and $\mathrm{Pgm}^{88}$ at $2.8 \%$ in Tarquinia. The populations from Tarquinia and S. Antioco are the only ones having private alleles. These results cannot be attributed to artificial 
Table 3

Allele frequencies at the 12 loci found to be polymorphic in the studied populations of A. salina

\begin{tabular}{|c|c|c|c|c|}
\hline Locus & Tarquinia & S. Antioco & Cagliari & Putzu Idu \\
\hline \multicolumn{5}{|c|}{$\alpha-G p d h$} \\
\hline 97 & - & 0.011 & - & - \\
\hline 100 & 1.000 & 0.989 & 1.000 & 1.000 \\
\hline \multicolumn{5}{|l|}{$M d h-1$} \\
\hline 90 & 0.006 & - & - & - \\
\hline 100 & 0.994 & 0.995 & 0.995 & 0.966 \\
\hline 115 & - & 0.005 & 0.005 & 0.034 \\
\hline \multicolumn{5}{|l|}{$M d h-2$} \\
\hline 100 & 0.983 & 0.990 & 1.000 & 1.000 \\
\hline 110 & 0.017 & 0.010 & - & - \\
\hline \multicolumn{5}{|l|}{$I d h-1$} \\
\hline 92 & 0.224 & 0.232 & 0.382 & - \\
\hline 100 & 0.776 & 0.768 & 0.618 & 1.000 \\
\hline \multicolumn{5}{|l|}{$I d h-2$} \\
\hline 85 & 0.007 & - & - & 0.020 \\
\hline 90 & - & 0.089 & - & - \\
\hline 92 & 0.007 & - & - & - \\
\hline 100 & 0.986 & 0.911 & 1.000 & 0.980 \\
\hline \multicolumn{5}{|l|}{$6 P g d h$} \\
\hline 100 & 0.418 & 0.238 & 0.570 & 0.271 \\
\hline 106 & - & 0.006 & - & - \\
\hline 112 & 0.160 & 0.287 & 0.160 & 0.431 \\
\hline 120 & 0.361 & 0.415 & 0.260 & 0.257 \\
\hline 127 & - & 0.006 & - & - \\
\hline 135 & 0.061 & 0.049 & 0.010 & 0.042 \\
\hline \multicolumn{5}{|l|}{ Sod } \\
\hline 95 & - & 0.020 & 0.008 & - \\
\hline 100 & 0.937 & 0.760 & 0.629 & 0.711 \\
\hline 107 & 0.062 & 0.220 & 0.363 & 0.289 \\
\hline \multicolumn{5}{|l|}{ Aat-1 } \\
\hline 90 & 0.083 & 0.133 & 0.111 & - \\
\hline 100 & 0.917 & 0.867 & 0.889 & 1.000 \\
\hline \multicolumn{5}{|l|}{ Pep-B } \\
\hline 94 & 0.063 & 0.014 & - & 0.020 \\
\hline 100 & 0.937 & 0.986 & 1.000 & 0.980 \\
\hline \multicolumn{5}{|l|}{$M p i$} \\
\hline 75 & 0.008 & 0.006 & 0.056 & - \\
\hline 82 & 0.038 & 0.032 & - & - \\
\hline 88 & 0.195 & 0.083 & 0.247 & 0.250 \\
\hline 93 & 0.148 & 0.141 & 0.056 & 0.303 \\
\hline 97 & 0.140 & 0.173 & 0.167 & 0.079 \\
\hline 100 & 0.470 & 0.564 & 0.475 & 0.368 \\
\hline \multicolumn{5}{|l|}{ Gpi } \\
\hline 95 & 0.010 & 0.030 & - & - \\
\hline 100 & 0.980 & 0.963 & 1.000 & 0.981 \\
\hline 108 & 0.010 & 0.007 & - & 0.019 \\
\hline \multicolumn{5}{|l|}{ Pgm } \\
\hline 88 & 0.028 & - & - & - \\
\hline 95 & 0.233 & 0.080 & 0.150 & 0.265 \\
\hline 100 & 0.712 & 0.375 & 0.539 & 0.596 \\
\hline 105 & 0.028 & 0.545 & 0.311 & 0.140 \\
\hline
\end{tabular}

sampling because a comparable number of specimens have been analysed for each sample (see Table 1).

No statistically significant deviations from Hardy-Weinberg expectations were seen in any of the studied samples.
Table 4

Parameters of genetic variability in the studied populations of A. salina

\begin{tabular}{|c|c|c|c|}
\hline Samples & $A$ & $P_{99}$ & $H_{0}$ \\
\hline Tarquinia & 39 & 0.61 & 0.135 \\
\hline S. Antioco & 41 & 0.67 & 0.184 \\
\hline Cagliari & 32 & 0.39 & 0.165 \\
\hline Putzu Idu & 31 & 0.44 & 0.141 \\
\hline
\end{tabular}

All amphigonic populations have similar levels of genetic variability, with a mean observed heterozygosity $H_{\mathrm{o}}$ ranging between 0.135 and 0.184 , a total number of recorded alleles $A$ between 31 and 41, and a percentage of polymorphic loci $P_{99}$ from 0.39 to 0.67 Table 4). Nei's genetic distances have been calculated to estimate the extent of genetic differentiation between the studied samples Table 5. $D_{\text {Nei }}$ ranged between 0.013 and 0.021 , showing that populations are genetically closely related and that there is a scarce differentiation among them, as confirmed by the low value of mean $F_{\text {ST }}$ (0.061) (Wright, 1943, 1951) and by the close values assumed by $F_{\text {IS }}$ and $F_{\text {IT }}$ at single loci (see Table 6. Although the studied populations are not geographically adjacent, being separated by the Tyrrhenian Sea, the low observed differentiation gives evidence of a moderate gene flow among them $(N m=2.2)$.

\subsection{Genetic structure in parthenogenetic populations}

Genotypic frequencies based on observed phenotypes at the 18 scored loci Table 7 were considered to analyse the genetic structure of parthenogenetic populations. All the three tetraploid samples have private alleles: Comacchio has eight private alleles, Cervia seven and M. Savoia (tetraploid) two. Private alleles have not been found in the diploid parthenogenetic strain from M. Savoia. The four populations have fixed different genotypes at many loci (Table 7). Even between Cervia and Comacchio, geographically neighbouring and both tetraploid, fixed differences have been recorded at 11 of the 18 scored loci ( $\alpha-G p d h, M d h-1, I d h-1, I d h-2$, 6Pgdh, Aat-1, Ald, Ca, Mpi, Gpi, Pgm).

Each population presents few genotypes, well distinguished from those of the other populations. For example, Comacchio sample shows a single genotype for all the 18 scored loci in all the studied specimens, and at seven loci the allelic array is unique ( $\alpha-G p d h, I d h-1$, Aat-1, Ca, Mpi, Gpi, $P g m$ ), having never been observed in the other studied populations.

The values of observed heterozygosity for parthenogenetic populations are given in Fig. 1 The range of observed values is very wide. The tetraploid samples Cervia and tetraploid M. Savoia, have quite similar values of $H_{\mathrm{o}}(0.39$ and 0.28 , respectively), while Comacchio sample has a strikingly high level of heterozygosity, 0.72. The diploid sample from M. Savoia exhibits a lower level of heterozygosity, 0.15 . The high genetic variability observed in tetraploid samples can be 
Table 5

Matrix of Nei's (1972) genetic distance coefficients

\begin{tabular}{|c|c|c|c|c|c|c|c|c|c|}
\hline & Population & 1 & 2 & 3 & 4 & 5 & 6 & 7 & 8 \\
\hline 1 & Tarquinia & $*$ & & & & & & & \\
\hline 2 & S. Antioco & 0.019 & $*$ & & & & & & \\
\hline 3 & Cagliari & 0.014 & 0.013 & $*$ & & & & & \\
\hline 4 & Putzu Idu & 0.013 & 0.019 & 0.021 & $*$ & & & & \\
\hline 5 & Cervia & 0.734 & 0.720 & 0.741 & 0.802 & $*$ & & & \\
\hline 6 & Comacchio & 0.540 & 0.577 & 0.557 & 0.599 & 0.266 & $*$ & & \\
\hline 7 & M. Savoia Dip & 0.907 & 0.912 & 0.922 & 0.976 & 0.208 & 0.253 & $*$ & \\
\hline 8 & M. Savoia Tet & 0.791 & 0.793 & 0.813 & 0.836 & 0.223 & 0.249 & 0.098 & $*$ \\
\hline
\end{tabular}

Table 6

Wright's $F$ statistics calculated for polymorphic loci of A. salina

\begin{tabular}{lrrll}
\hline Locus & \multicolumn{1}{l}{$F_{\text {IS }}$} & \multicolumn{1}{l}{$F_{\text {IT }}$} & \multicolumn{1}{l}{$F_{\text {ST }}$} & \\
\hline$\alpha-G p d h$ & -0.011 & -0.003 & 0.009 & NS \\
Mdh-1 & -0.026 & -0.011 & 0.014 & NS \\
Mdh-2 & -0.015 & -0.007 & 0.008 & NS \\
Idh-1 & -0.035 & 0.081 & 0.112 & $*$ \\
Idh-2 & 0.148 & 0.187 & 0.045 & NS \\
6Pgdh & 0.068 & 0.115 & 0.051 & $*$ \\
Sod & -0.113 & -0.037 & 0.068 & $*$ \\
Aat-1 & -0.128 & -0.089 & 0.034 & NS \\
Pep-B & 0.064 & 0.086 & 0.024 & NS \\
Mpi & 0.116 & 0.141 & 0.028 & NS \\
Gpi & -0.025 & -0.015 & 0.010 & NS \\
Pgm & -0.089 & 0.018 & 0.098 & $*$ \\
Mean & 0.006 & 0.067 & 0.061 & NS \\
\hline
\end{tabular}

$* P<0.01$.

NS, not significant $(P>0.01)$.

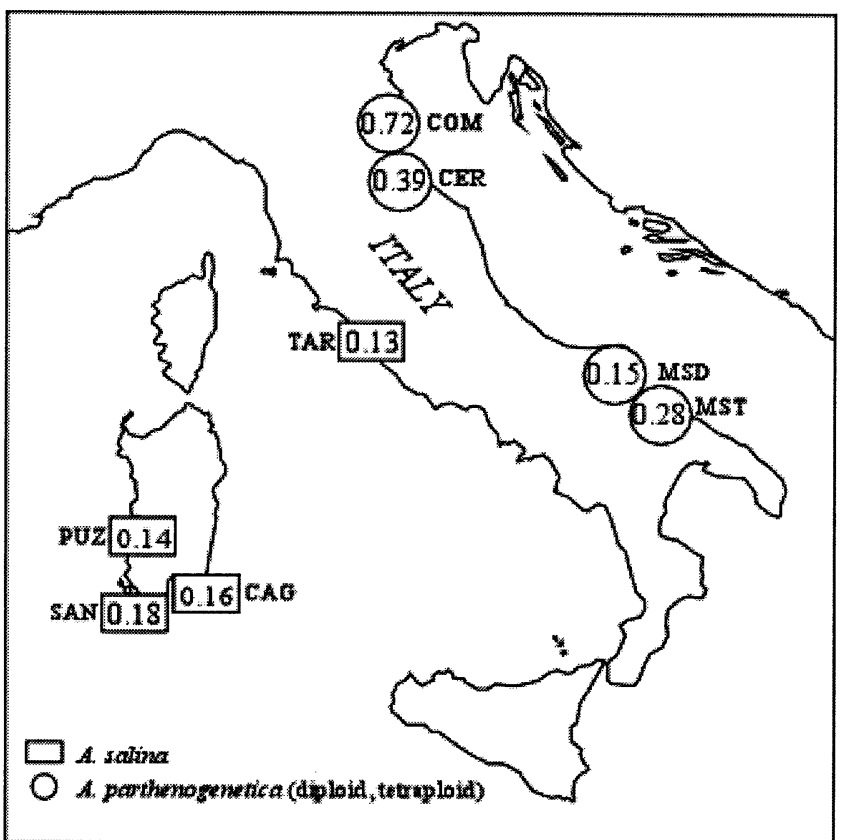

Fig. 1. Values of observed heterozygosity $\left(H_{0}\right)$ for the studied populations of A. salina and A. parthenogenetica. Abbreviations as reported in Table 1 due to the fixed heterozygosity found at several loci, for two or three alleles. Comacchio sample shows a fixed heterozygosity at 13 of the 18 studied loci, while Cervia and M. Savoia tetraploid strains have five loci with fixed heterozygosity. Cervia shows two or three alleles at heterozygous fixed loci and M. Savoia always shows two. Also, the diploid sample from M. Savoia has fixed heterozygosity at two loci (6Pgdh, Pgm), with two alleles each.

$D_{\mathrm{Nei}}$ values show a substantial genetic differentiation among the studied populations, ranging between 0.098 (observed between the two samples from M. Savoia, diploid and tetraploid) and 0.266 (between Comacchio and Cervia).

These results show that $A$. parthenogenetica is a heterogeneous group of clones characterised by a strong genetic differentiation, even within the same group of ploidy.

\subsection{Genetic differentiation within and between A. salina and $\mathrm{A}$. parthenogenetica}

The dendrogram in Fig. 2 represents genetic relationships based on Nei's distances calculated among populations. High genetic distances were detected between bisexual and parthenogenetic populations $\left(D_{\mathrm{Nei}}\right.$ from 0.540 to 0.976 , Table 5 which join two main sub-clusters. This is in good agreement with the belonging to the studied samples of two well-differentiated species: A. salina and A. parthenogenetica.

The sub-cluster including $A$. salina bisexual samples shows a low genetic distance among them $\left(D_{\mathrm{Nei}}\right.$ between 0.013 and 0.021), with a differentiation fully within the typical range of conspecific local populations (Hedgecock et al., 1982).

Within parthenogenetic populations, M. Savoia diploid and tetraploid samples show the highest affinity and are linked to the North Adriatic population from Cervia (mean distance 0.215). Comacchio sample is the most differentiated, being on a separate branch with respect to the other parthenogenetic populations, with an average distance of 0.256 . This is also due to the high number of exclusive alleles (8) found in this population. It can be noted that the two nearby polyploid North Adriatic samples (Cervia and Comacchio) have a conspicuous genetic distance (0.266), mostly due to the high number of exclusive alleles found in each population, observed at 10 loci out of the 18 analysed. 
Table 7

Genotypic frequencies based on observed phenotypes at the 18 loci analysed in A. parthenogenetica populations. Common alleles with A. salina evidenced in bold

\begin{tabular}{|c|c|c|c|c|}
\hline Genotype & Cervia & Comacchio & $\begin{array}{l}\text { M. Savoia } \\
\text { dip }\end{array}$ & M. Savoia tet \\
\hline \multicolumn{5}{|l|}{$\overline{\alpha-G p d h}$} \\
\hline $100 / 110$ & - & 1.000 & - & - \\
\hline $110 / 110$ & - & - & 1.000 & 1.000 \\
\hline $110 / 120$ & 1.000 & - & - & - \\
\hline \multicolumn{5}{|l|}{$L d h$} \\
\hline $100 / 100$ & 1.000 & 1.000 & 1.000 & 1.000 \\
\hline \multicolumn{5}{|l|}{$M d h-1$} \\
\hline $100 / 110$ & 0.086 & - & - & - \\
\hline $110 / 110$ & 0.914 & - & 1.000 & - \\
\hline $110 / 118$ & - & 1.000 & - & 1.000 \\
\hline \multicolumn{5}{|l|}{$M d h-2$} \\
\hline $100 / 110$ & 0.065 & 1.000 & - & - \\
\hline $110 / 110$ & 0.935 & - & 1.000 & - \\
\hline $105 / 110$ & - & - & - & 1.000 \\
\hline \multicolumn{5}{|l|}{$M d h p$} \\
\hline $100 / 100$ & 1.000 & 1.000 & 1.000 & 1.000 \\
\hline \multicolumn{5}{|l|}{$I d h-1$} \\
\hline 92/92 & 0.866 & - & - & - \\
\hline 92/96 & 0.067 & - & - & - \\
\hline 92/98 & - & 1.000 & - & - \\
\hline $96 / 96$ & 0.067 & - & 1.000 & - \\
\hline $96 / 100$ & - & - & - & 1.000 \\
\hline \multicolumn{5}{|l|}{$I d h-2$} \\
\hline $96 / 96$ & - & - & 0.677 & - \\
\hline $96 / 104$ & - & 1.000 & 0.323 & - \\
\hline 100/104 & 0.956 & - & - & - \\
\hline $104 / 104$ & 0.044 & - & - & 1.000 \\
\hline \multicolumn{5}{|l|}{$6 P g d h$} \\
\hline $100 / 106$ & - & 1.000 & 1.000 & 1.000 \\
\hline $106 / 112$ & 1.000 & - & - & - \\
\hline \multicolumn{5}{|l|}{ Sod } \\
\hline $100 / 100$ & 1.000 & 1.000 & 1.000 & 1.000 \\
\hline \multicolumn{5}{|l|}{ Aat-1 } \\
\hline $82 / 90$ & - & 1.000 & - & - \\
\hline $90 / 90$ & 1.000 & - & 1.000 & 1.000 \\
\hline \multicolumn{5}{|l|}{ Aat-2 } \\
\hline $115 / 115$ & 1.000 & 1.000 & 1.000 & 1.000 \\
\hline \multicolumn{5}{|l|}{ Est } \\
\hline $100 / 100$ & 1.000 & 1.000 & 1.000 & 1.000 \\
\hline \multicolumn{5}{|l|}{ Pep-B } \\
\hline $96 / 96$ & 0.643 & - & 1.000 & 1.000 \\
\hline $96 / 100$ & 0.214 & 1.000 & - & - \\
\hline $100 / 100$ & 0.143 & - & - & - \\
\hline \multicolumn{5}{|l|}{ Ald } \\
\hline $92 / 100$ & - & 1.000 & 0.429 & - \\
\hline $100 / 100$ & - & - & 0.571 & 1.000 \\
\hline $100 / 105$ & 0.600 & - & - & - \\
\hline $105 / 105$ & 0.400 & - & - & - \\
\hline $\mathrm{Ca}$ & & & & \\
\hline $100 / 100$ & 1.000 & - & 1.000 & 1.000 \\
\hline $100 / 110$ & - & 1.000 & - & - \\
\hline$M p i$ & & & & \\
\hline 93/103/105 & - & 1.000 & - & - \\
\hline $100 / 103$ & 1.000 & - & - & - \\
\hline $103 / 103$ & - & - & 1.000 & 1.000 \\
\hline Gpi & & & & \\
\hline $95 / 110$ & 1.000 & - & - & - \\
\hline $100 / 110$ & - & 1.000 & - & - \\
\hline $110 / 110$ & - & - & 1.000 & 1.000 \\
\hline$P g m$ & & & & \\
\hline $95 / 100$ & - & - & 0.015 & - \\
\hline $95 / 100 / 105$ & 1.000 & - & - & - \\
\hline $95 / 100 / 115$ & - & 1.000 & - & - \\
\hline $100 / 105$ & - & - & 0.985 & 1.000 \\
\hline
\end{tabular}

\section{Discussion}

The presented results add some data to the knowledge of the widely studied genetics of Italian Artemia populations. The main data obtained concern the degree of genetic differentiation between and within populations of A. salina and A. parthenogenetica and their levels of genetic variability.

The results obtained on genetic differentiation show that brine shrimp bisexual populations are genetically similar, with a moderate gene flow able to counteract genetic drift effect and to maintain genetic homogeneity between populations from far areas, i.e. Sardinia Island and Tyrrhenian Italian coasts. Maybe not all the assumptions needed to calculate gene flow rates are satisfied in Artemia populations. For example, the absence of selective forces is one assumption of the model, but it has been repeatedly suggested that selection could act on local populations of many Artemia species (Browne and Hoopes, 1990; Browne et al., 2002). However, the obtained rates of gene flow seem consistent with the effectiveness of the dispersal mechanisms of the species, that are usually carried out by the desiccationresistant cysts and assisted by migratory waterfowl that can cover very long distances, allowing a gene flow able to counteract genetic drift effects $(\mathrm{Nm}>1)$ even between populations located in relatively far away areas, such as Sardinia and Latium. Accordingly, previous electrophoretic studies carried out by Abreu-Grobois and Beardmore (1982) on Mediterranean populations of $A$. salina showed a range of genetic distances comparable to that reported here $\left(D_{\mathrm{Nei}}\right.$ $0.01-0.02$ against $0.01-0.06$ ), with slightly higher values limited to very far away samples (Spain against Cyprus). The levels of genetic variability observed are close to those evidenced in other bisexual Artemia species. For example, the observed heterozygosity ranges from 0.135 to 0.184 , while a range of 0.096-0.138 was recently found using allozymes by Abatzopoulos et al. (2002) in populations of A. franciscana, A. urmiana, A. sinica and A. tibetiana. The genetic differentiation between parthenogenetic populations is about one order of magnitude greater than among bisexual samples ( $\left.D_{\mathrm{Nei}} 0.098-0.266\right)$. These findings confirm that $A$. pathenogenetica is a cluster of very differentiated forms. However, previous electrophoretic studies evidenced strong differentiation mainly between forms characterised by different ploidies, while polyploid populations from the whole Mediterranean basin were shown as having similar genotypes (Abreu-Grobois and Beardmore, 1982). Other results obtained by Perez et al. (1994) comparing the mitochondrial DNA of diploid and tetraploid Spanish strains of A. parthenogenetica, showed them to be highly differentiated. While confirming the differentiation between strains with different ploidies, our results also highlight a noticeable differentiation even between polyploid neighbouring populations (Comacchio and Cervia; $D_{\mathrm{Nei}} 0.266$ ), comparable to that observed between diploid/polyploid forms (M. Savoia diploid vs. Comacchio and Cervia; $D_{\mathrm{Nei}}$ 0.230). The estimates of genetic variability show high heterozygosity for the three tetraploid parthenogenetic populations, in particular, in the 


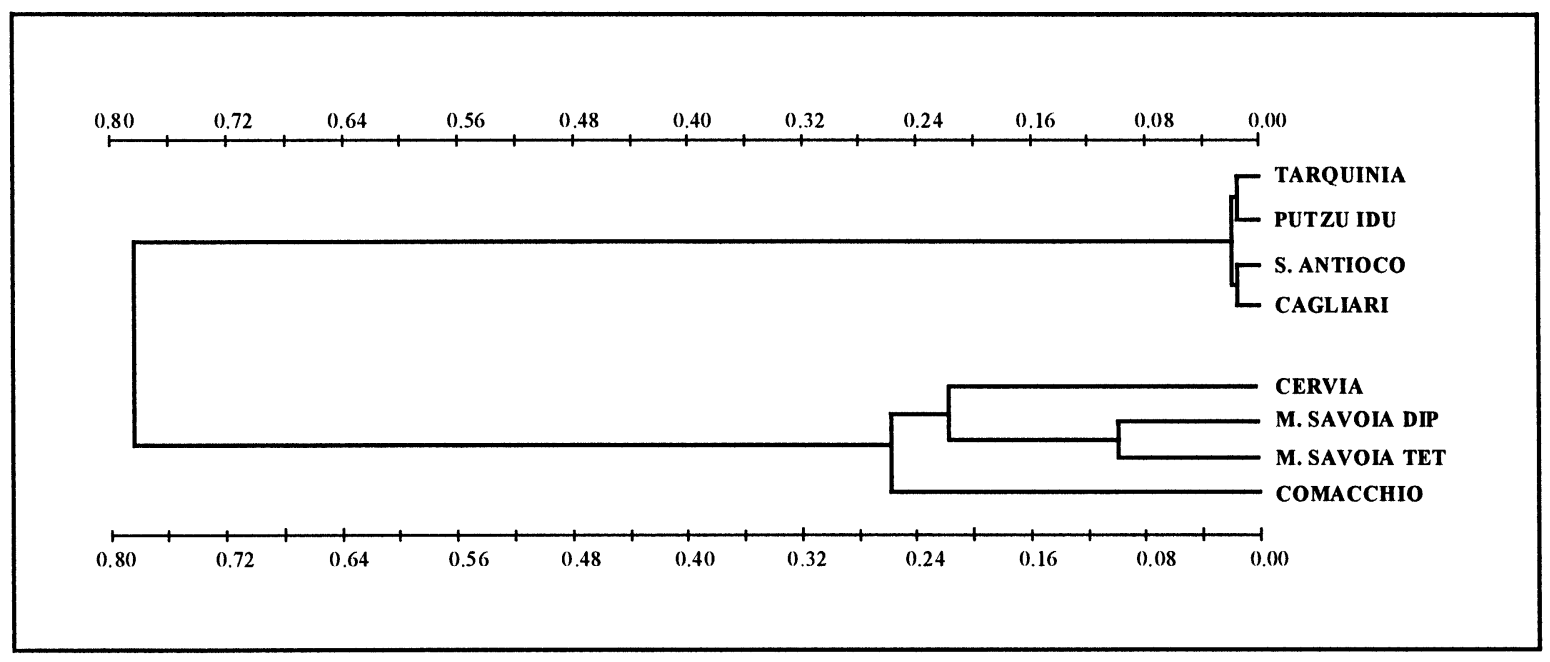

Fig. 2. Unweighted pair group method with arithmetic mean (UPGMA) dendrogram based on Nei's (1972) genetic distances.

tetraploid sample from Comacchio. This variability can be attributed to the fixation of heterozygous genotypes in all the studied individuals at many loci. Such a striking value $\left(H_{\mathrm{o}}=\right.$ 0.72 ) is due to the fixation in heterozygosity of a relevant percentage of the studied loci, 13 out of the 18 analysed. Similar levels of fixed heterozygosity, supporting our explanation, were found, but not stressed, by Abreu-Grobois and Beardmore (1982) in tetraploid samples from Spain and France.

According to the usually accepted theories on evolutionary biology of brine shrimp, these data could be explained by the evolutionary history of $A$. parthenogenetica. The high heterozygosity evidenced here could be generated by mutation or recombination in diploid Artemia, while, in polyploid forms, only mutation could create variation (Barigozzi, 1974). Once this heterozygosity originates, it could be maintained by selective pressure due to environmental conditions (Zhang and King, 1992). Within this frame, mutations would account for the high heterozygosity recorded in polyploid forms, while different environmental conditions could be responsible for the selective fixation in heterozygosity of many loci and for the high genetic divergence observed between either diploid/polyploid or polyploid populations. Ecological knowledge supports this explanation, because it is well known that a range of environmental parameters, such as temperature, salinity, UV radiation and more, play a relevant role in moulding the genetic structure of Artemia local populations (Bowen et al., 1988; Browne and Hoopes, 1990; Lenz and Browne, 1991; Browne, 1992).

An alternative working hypothesis could be formulated. In fact, it is known that other unisexual invertebrate species, also living in rather extreme environments, originated by hybridisation (White, 1978; Nascetti and Bullini, 1980; Bullini and Nascetti, 1990; Bullini, 1994). There is growing evidence that hybridisation can generate clonal diversity (Butlin et al., 1998), since this process has been proved in some unisexual animal species (Avise et al., 1992; Bullini, 1994; Vrijenhoek, 1994). According to the "reticulate evolu- tion" process (Darewsky, 1992), the random hybridisation between allopatrically differentiated bisexual taxa could give rise to new hybrid species, characterised by fixed heterozygosity at parental discriminating loci, non-amphigonic reproduction and frequent genome polyploidisation, as in the case of stick insects of the genus Bacillus (Bullini and Nascetti, 1990; Mantovani and Scali, 1992). Although quite rare, hybrid animal species usually have a remarkable ecological success, leading to parental competitive displacement or to the colonisation of new habitats, unsuitable for parental species, as proved for the snail, Bulinus truncatus, the grasshopper, Warramaba virgo, or the stick insects belonging to the genus Clonopsis (White, 1978; Nascetti and Bullini, 1980; Bullini and Nascetti, 1990; Bullini, 1994). Some strains of A. parthenogenetica (e.g. tetraploid Comacchio population) display many of these features, being characterised by a high number of fixed heterozygous loci, apomictic parthenogenetic reproduction and tetraploidy. Moreover, it has been experimentally demonstrated that $A$. parthenogenetica competitively displaces the sympatric sexual species, A. salina (Browne et al., 1988; Browne and Halanych, 1989). Considering that on an overall number of 44 alleles observed in A. parthenogenetica, 24 are common with $A$. salina, this species could be a good candidate for being one of parental bisexual species. Nevertheless, locus Aat-2 is fixed for alternative alleles in the two species, so that a common ancestor (with a gene pool close to that of extant A. salina) as a parental species of $A$. parthenogenetica seems a more reasonable hypothesis.

In conclusion, if the hypothesis of the origin of some polyploid brine shrimps by hybridisation cannot be excluded, its demonstration needs further studies aimed at identifying the bisexual parental species of $A$. parthenogenetica.

\section{Acknowledgements}

This study was fully supported by the Italian Ministero dell'Università e Ricerca Scientifica e Tecnologia (MURST) 
within a national research project on biodiversity in brackish waters (1997 and 1999).

We are grateful to Dr. Daniela Willelms for reviewing the English text of the manuscript.

We are also indebted to three anonymous referees for their useful suggestions, thus greatly improving the manuscript.

\section{References}

Abatzopoulos, T.J., Kappas, I., Bossier, P., Sorgeloos, P., Beardmore, J.A., 2002. Genetic characterization of Artemia tibetiana (Crustacea: Anostraca). Biol. J. Linn. Soc. 75, 333-344.

Abreu-Grobois, F.A., Beardmore, J.A., 1982. Genetic differentiation and speciation in the brine shrimp, Artemia. In: Barigozzi, C. (Ed.), Mechanisms of Speciation. Alan R. Liss, Inc., New York, USA, pp. 345-376.

Avise, J.C., Quattro, J.M., Vrijenhoek, R.C., 1992. Molecular clones within organismal clones: mitochondrial DNA phylogenies and the evolutionary histories of unisexual vertebrates. Evol. Biol. 26, 225-246.

Ayala, F., Powell, J.R., Tracey, M.L., Mourao, C.A., Perez-Salas, S., 1972. Enzyme variability in Drosophila willistoni group. IV. Genetic variation in natural population of Drosophila willistoni. Genetics 70, 113-139.

Badaracco, G., Bellorini, M., Landsberger, N., 1995. Phylogenetic study of bisexual Artemia using random amplified polymorphic DNA. J. Mol. Evol. 41, 150-154.

Barigozzi, C., 1974. Artemia: a survey of its significance in genetic problems. Evol. Biol. 7, 221-252.

Bowen, S.T., Buoncristiani, M.R., Carl, J.R., 1988. Artemia habitats: ion concentrations tolerated by one superspecies. Hydrobiologia 158, 201-214.

Bowen, S.T., Durking, J.P., Sterling, G.S., Clark, L.S., 1978. Artemia haemoglobins: genetic variation in parthenogenetic and zygogenetic populations. Biol. Bull. 155, 273-287.

Bowen, S.T., Sterling, G.S., 1978. Esterase and malate dehydrogenase isozyme polymorphism in 15 Artemia populations. Comp. Biochem. Physiol. 61, 593-595.

Brewer, G.J., Sing, C.F., 1970. An Introduction to Isozyme Techniques. Academic Press, New York and London.

Browne, R.A., 1983. Results of cross-breeding experiments in Mediterranean sexual populations of Artemia. Biol. Bull. 165, 506.

Browne, R.A., 1988. Ecological and genetic divergence of sexual and asexual brine shrimp (Artemia) populations from the Mediterranean basin. Nat. Geogr. Res. 4, 548-554.

Browne, R.A., 1992. Population genetics and ecology of Artemia: insights into parthenogenetic reproduction. Trends Ecol. Evol. 7, 232-237.

Browne, R.A., Bowen, S.T., 1991. Taxonomy and population genetics of Artemia. In: Browne, R.A., Sorgeloos, P., Trotman, C.A. (Eds.), Artemia Biology. CRC Press, Boca Raton, Florida, USA, pp. 221-236.

Browne, R.A., Davis, L.E., Sallee, S.E., 1988. Effects of temperature and relative fitness of sexual and asexual brine shrimp Artemia. J. Exp. Mar. Biol. Ecol. 124, 1-20.

Browne, R.A., Halanych, K.M., 1989. Competition between sexual and parthenogenetic Artemia: a re-evaluation (Branchiopoda, Anostraca). Crustaceana 57, 57-71.

Browne, R.A., Hoopes, C.W., 1990. Genotype diversity and selection in asexual brine shrimp (Artemia). Evolution 44, 1035-1051.

Browne, R.A., Macdonald, G.H., 1982. Biogeography of the brine shrimp, Artemia: distribution of parthenogenetic and sexual populations. J. Biogeogr. 9, 331-338.

Browne, R.A., Moller, V., Forbes, V.E., Depledge, M.H., 2002. Estimating genetic and environmental components of variance using sexual and clonal Artemia. J. Exp. Mar. Biol. Ecol. 267, 107-119.

Bullini, L., 1994. Origin and evolution of animal hybrid species. Trends Ecol. Evol. 9, 422-426.

Bullini, L., Nascetti, G., 1990. Speciation by hybridization in phasmids and other insects. Can. J. Zool. 68, 1747-1760.

Butlin, R., Schön, I., Martens, K., 1998. Asexual reproduction in nonmarine ostracods. Heredity $81,473-480$.
Crow, J.F., Aoki, K., 1984. Group selection for a polygenetic behavioural trait: estimating the degree of a population subdivision. Proc. Nat. Acad. Sci. USA 81, 6073-6077.

Darewsky, I.S., 1992. Evolution and ecology of parthenogenesis in reptiles. In: Adler (Ed.), Herpetology: Current Research on the Biology of Amphibians and Reptiles. Proc. First World Congress of Herpetology, pp. 21-39.

Goudet, J., 2001. FSTAT, a program to estimate and test gene diversities and fixation indices. Available from http://www.unil.ch/izea/softwares/ fstat.html (version 2.9.3).

Harris, H., Hopkinson, D.A., 1976. Handbook of Enzyme Electrophoresis in Human Genetics. North Holland Publishing Company Inc., New York, USA.

Hedgecock, D., Tracey, M.L., Nelson, K., 1982. Genetics. In: Abele, L.G. (Ed.), The Biology of Crustacea. Academic Press, New York, USA, pp. 283-403.

Lenz, P.H., Browne, R.A., 1991. Ecology of Artemia. In: Browne, R.A., Sorgeloos, P., Trotman, C.A. (Eds.), Artemia Biology. CRC Press, Boca Raton, Florida, USA, pp. 237-254.

Mantovani, B., Scali, V., 1992. Hybridogenesis and androgenesis in the stick-insect Bacillus rossius-grandii benazzii. Evolution 43, 783-796.

Mura, G., 1990. Artemia salina (Linnaeus, 1758) from Lymington, England: frontal knob morphology by scanning electron microscopy. J. Crust. Biol. 10, 364-368.

Nascetti, G., Bullini, L., 1980. Genetic differentiation in the Mandahlbarthia truncata complex (Gastropoda: Planorbidae). Parasitologia 22, 269-274.

Neel, H., 1973. Private variants and the frequency of mutation among South American Indians. Proc. Natl. Acad. Sci. USA 70, 3311-3315.

Nei, M., 1972. Genetic distance between populations. Am. Nat. 106, 283-292.

Perez, M.L., Valverde, J.R., Batuecas, B., Amat, F., Marco, R., Garesse, R., 1994. Speciation in Artemia genus: mitochondrial DNA analysis of bisexual and parthenogenetic brine shrimps. J. Mol. Evol. 38, 156-169.

Pilla, E.J.S., Beardmore, J.A., 1994. Genetic and morphometric differentiation in Old World bisexual species of Artemia (the brine shrimp). Heredity $73,47-56$.

Poulik, M.D., 1957. Starch gel electrophoresis in a discontinuous system of buffers. Nature 180, 1477.

Richardson, R.J., Baverstock, P.R., Adams, M., 1986. Allozyme Electrophoresis. Academic Press, London.

Selander, R.K., Smith, M.H., Yang, S.Y., Johnson, W.E., Gentry, J.B., 1971. Biochemical polymorphism and systematics in the genus Peromyscus. Variation in the old field mouse (Peromyscus polionotus). Univ. Tex. Publ. 103, 49-69.

Shaw, C.R., Prasad, R., 1970. Starch gel electrophoresis of enzymes: a compilation of recipes. Biochem. Genet. 4, 297-320.

Swofford, D.L., Selander, R.B., 1989. Biosys-1: a computer programme for the analysis of allelic variation in genetics and biochemical systematics. Release 1.7. Department of Genetics and Development, University of Illinois, Urbana-Champaign, Illinois.

Triantaphyllidis, G.V., Criel, G.R.J., Abatzopoulos, T.J., Thomas, K.M., Peleman, J., Beardmore, J.A., Sorgeloos, P., 1997. International study on Artemia. LVII. Morphological and molecular characters suggest conspecificity of all bisexual European and North African Artemia populations. Mar. Biol. 129, 477-487.

Vrijenhoek, R.C., 1994. Unisexual fish: model systems for studying ecology and evolution. Ann. Rev. Ecol. Syst. 25, 71-96.

White, M.J.D., 1978. Modes of Speciation. W.H. Freeman and Company, San Francisco.

Workman, P.L., Niswander, J.D., 1970. Population studies on Southwestern Indian tribes. II. Local genetic differentiation in the Papago. Am. J. Hum. Genet. 22, 24-49.

Wright, S., 1943. Isolation by distance. Genetics 28, 114-138.

Wright, S., 1951. The genetical structure of populations. Ann. Eugen. London 15, 323-345.

Zhang, L., King, C.E., 1992. Genetic variation in sympatric populations of diploid and polyploid brine shrimp (Artemia parthenogenetica). Genetica 85, 211-221. 